\title{
SLE Thrombocytopenia: From Peripheral Platelet Destruction to Central Hemopoietic Defect
}

\author{
Panayiotis D. Ziakas* \\ “Hygeia” Diagnostic \& Therapeutic Centre. 9 Erythrou Stavrou St. 15123 Athens, Greece
}

\begin{abstract}
Thrombocytopenia in Systemic Lupus Erythematosus is a common clinical manifestation affecting up to one third of patients in published cohorts. Antiplatelet antibodies, antithrombopoietin antibodies and faulty hemopoiesis have been implicated among other immunologic and non-immunologic causes. This mini review is an uptodate summary of these immunologic phenomena.
\end{abstract}

\section{INTRODUCTION}

Thrombocytopenia, a generally benign complication of Systemic Lupus Erythematosus (SLE), largely reflects the disease activity in other systems and has recently been associated with long-term, irreversible organ damage [1-4]. The field of pathophysiology is rendered even more intriguing with autoantibodies against platelets, autoantibodies against thrombopoietin and bone marrow abnormalities constituting a puzzle of interactions related to this clinical phenomenon $[5]$.

\section{ANTIPLATELET ANTIBODIES: NOT ALWAYS TO BLAME}

Immune platelet destruction in SLE is mediated through autoantibodies against their membrane glycoproteins. Humoral platelet destruction was first described by Harrington in 1951 [6] and the specific binding of autoantibodies to major platelet glycoproteins as previously described by Kurata, is considered as the basic immunologic disturbance related to thrombocytopenia [7].

\section{Antigenic Targets}

The main antigenic target is GpIIb/IIIa complex, which mediates platelet aggregation by binding adhesion proteins, including fibrinogen and von Willebrand factor (wWF), whilst autoantibodies against GpIb/IX and GpIa/IIa are detected less often [8,9]. The GpIIb/IIIa (CD41/CD61) complex is unique for the megakaryocyte (MK) lineage with 50,000 molecules being expressed on the platelet surface [10], constituting $3 \%$ of its total mass and $17 \%$ of its membrane mass. Both GpIIb and GpIIIa are glycosylated [11,12] and form a heterodimeric complex non-covalently linked to the rough endoplasmic reticulum [13]. In Glanzmann's thrombasthenia they are both absent, leading to a lack of aggregation in response to common platelet agonists $[14,15]$. The GpIb/IX/V (CD42), otherwise vWF receptor, is also unique for the MK lineage, even though similar proteins may be expressed by activated endothelial cells in response to cytokines [16]. The Bernard-Soulier syndrome is character-

*Address correspondence to this author at the "Hygeia" Diagnostic \& Therapeutic Centre. 9 Erythrou Stavrou St. 15123 Athens, Greece; Tel: +30-210-6867311; Fax: +30-210-6867299; E-mail: zpanos@otenet.gr ized by bleeding diathesis, thrombocytopenia with giant platelets, no response to ristocetin-induced aggregation and lack of the receptor [17]. Finally the GpIa/IIa complex (CD49b/CD29) (collagen receptor) facilitates collagen adhesion and is being expressed in various cell subtypes, with 1000 molecules present on the platelet surface [18].

\section{Antibody-Mediated Clearance of Platelets}

Sensitized platelets are removed from the circulation through interaction of autoantibodies Fc portion with macrophages. Their Fc Receptors (FcR) recognize the Fc part of IgG immunoglobulins, bridging humoral with cell-mediated immunity. Among the three distinct subtypes of FcR, i.e. FcRI (CD64), FcRII(CD32) and FcRIII(CD16) [19,20], only FcRII and FcRIII are implicated in platelet clearance from the circulation [21-23]. Fehr was the first to show that human immunoglobulin increases survival of anti-D sensitized erythrocytes in patients with immunologic purpura, a finding conceived as direct proof of phagocytic inhibition through FcR in so far as sensitized erythrocytes are cleared through this pathway only [24]. The net impact of the FcR system is determined by the balance between the stimulating effect of FcRIIA and FCRIIIA, and the inhibitory effect of FcRIIB of macrophage. Although the regulatory mechanism is unclear, each receptor effect seems to correlate with a discrete response to treatment. Specifically anti-D globulin response depends on FcRIIA [25], and rituximab response on FcRIIIA (at least in lymphomas). Experimental models have shown that response to intravenous immunoglobulin (IVIG) depends on FcRIIB [26] and mice not expressing FcRIIB have no therapeutic benefit. In humans, the treatment effect is regulated through upregulation of expression of the inhibitory FcRIIB [27].

\section{Detection of Antiplatelet Antibodies}

The last four decades have seen the advent of several methods for detecting antiplatelet antibodies. Chronologically they can be classified in three groups. The first group, that measured functional deviations of normal platelets incubated with patients' sera, was abandoned due to low sensitivity and specificity [28-30]. The second group measured the IgG bound to platelets (Platelet associated IgG, PAIgG) [31]. High levels of PAIgG characterized patients with immu- 
nologic purpura and were considered to represent antiplatelet antibodies located on the platelet surface [32,33]. However, accumulated evidence suggested that normal platelets have two IgG pools, one located on platelet surface (100 IgG molecules) and one intracellular pool $(20,000 \mathrm{IgG}$ molecules) $[34,35]$. Older methods also measured the $\operatorname{IgG}$ of $\alpha$ granules, leading to falsely elevated results for surface $\operatorname{IgG}$ [36-38]. Surface immunoglobulin was later measured with I131-labeled monoclonal antibody for all IgG subclasses or labeled staphylococcal protein A [39-41]. In AITP surface immunoglobulin may be elevated, but this finding is also observed in non-immunologic thrombocytopenias and marrow failure. Therefore, these methods whilst sensitive (80$90 \%$ ) were not specific, as they were unable to discriminate between normal and abnormal IgG.

The third group involved current methods (ELISA, MAIPA) which detect antiplatelet antibodies against specific surface glycoproteins and are considered specific, although lacking in sensitivity (47-60\%) [42].

Direct MAIPA (Monoclonal Assay Immobilization of Platelet Antigens) has an estimated sensitivity of $49-66 \%$ and a specificity of $78-92 \%$, with a positive predictive value of $80-83 \%$ [43-45]. A negative test can not exclude the diagnosis $[44,46]$, and detection of circulating serum autoantigens is even less sensitive. Concordance between various laboratories for binded autoantibody is $55-67 \%$ and less for plasma [47]. Their prognostic value is narrowed when SLE emerges among the differential diagnosis of thrombocytopenia, as well as chronic hepatitis, myelodysplasia and lymphomas [48,49] and AITP cannot be differentiated from secondary immunologically-mediated thrombocytopenias [50]. New generation, antigen-specific ELISAs can also detect circulating autoantibodies, using specific monoclonal antibodies, bearing the limitations of MAIPA including loss of unusual antigenic targets (should the specific monoclonal antibody is not available), or loss of usual antigenic targets if the binding epitope of the monoclonal antibody is the same as that of the with autoantibody.

Despite the high prevalence of these antibodies among thrombocytopenic subjects, a number of patients display thrombocytopenia without anti-PLT positivity whilst a significant proportion of anti-PLT positive patients have never developed thrombocytopenia. Moreover, a correlation between anti-PLT antibodies and lower platelet counts is not always evident. [7,51,52]. However the fact that anti-PLTs are absent in the sera of SLE patients who recovered from thrombocytopenia after receiving immunosuppressive treatment, confirms a potential pathogenetic role, though not an exclusive one. Circulating and platelet-bound anti-PLTs are noted in significant proportion of patients (SLE, AITP) who have active thrombocytopenia. In contrast, when platelets normalize in responders, they become undetectable or decrease significantly and reappear in relapse $[44,47,53]$.

In a recent series of SLE patients, autoantibodies against platelet membrane antigens were detected in the sera of $29 \%$ of patients, $88 \%$ of which targeted the Gp IIb/IIIa complex and less frequently the Gp Ia/IIa, HLA I and Gp Ib/Ix complex. Almost $16 \%$ of patients had multiple antigenic targets. The prevalence of antiplatelet antibodies in the thrombocytopenic and non-thrombocytopenic groups did not differ, accounting for about $40 \%$ in each group. Notably, none of the post-thrombocytopenic individuals exhibited autoantibody activity against platelets. This latter group had received immunosuppressive therapy and achieved normal platelet counts [53].

\section{SLE Thrombocytopenia vs AITP}

Even though antiplatelet antibodies recognize the same membrane glycoproteins both in SLE and AITP, the immunopathogenesis appears different. AITP is considered as an organ-specific autoimmune disorder, related to molecular mimicry, cryptic epitope spreading, Th1/Th1 imbalance and an abnormal profile of cytokines that initiate the immunologic disturbance [54,55]. The latter is characterized by shift to Th1 response with depression of Th2 cells [56,57]. Conversely, when AITP is in remission, a Th2 shift is observed [58]. Moreover, AITP patients display increased HLA-DR expression, the recognition molecule for CD4+ TCR, which is considered to be the basic initiator of T-cell dependent immunologic response. Indeed, increased T-cell activity is observed in AITP whereas patients with SLE thrombocytopenia do not express HLA-DR on their platelets nor expand specific T-cell clones in the presence of platelets [59-61]. Finally, AITP patients show evidence that autoantibody production is mediated through the oligoclonal expansion of B-cells after exposure to platelet antigens, using genetically predetermined and specific rearrangements of heavy and light chain genes [62]. These characteristics are not evident in SLE, suggesting that SLE thrombocytopenia is not a direct immunologic response against platelets and therefore not a true AITP [63]. Even though antiplatelet antibodies remain an acceptable mechanism of platelet destruction [64], other mechanisms have attracted attention.

\section{THROMBOPOIETIN \& ANTI-THROMBOPOIETIN ANTIBODIES: THE NEW SUSPECTS}

Human TPO is the crucial regulator of PLT production with five independent research groups having identified and established its significant role in normal hemopoiesis [6569]. It acts as a growth factor in the commited progenitor cells [colony-forming units of megakaryocytes (CFU-MK)], differentiates immature megakaryoblasts, inhibits apoptosis and leads finally to the release of normal platelets. Morphologically, it increases the number, size and ploidy of MK. It has no effect on normal platelets [70-72]. In vitro, the appearance of functional platelets occurs after 10-12 days after TPO stimulation of human CD34+ cells [73]. Its ability to promote the expansion and maturation of megakaryocytic lineage and its synergistic effect with other cytokines has been confirmed in subpopulations of human progenitor cells from the bone marrow [74-77], fetal marrow [78], peripheral blood [79-81] and umbilical cord [82].

The C-mpl receptor of TPO belongs to Type 1 membrane receptors, being expressed in CD34+ progenitor cells, in megakaryocytes and in normal platelets $[74,83]$. In experimental knock-out models, the homozygous deletion of the c$\mathrm{mpl}$ or TPO gene leads to peripheral thrombocytopenia with an $85-95 \%$ concurrent reduction of megakaryocytes in bone marrow, the remainder being characterized by nuclear immaturity, lack of cytoplasmic granules and organelles. A 70\% reduction is also observed in both erythroid and granulocytic lineages, confirming TPO synergistic role in early hemopoi- 


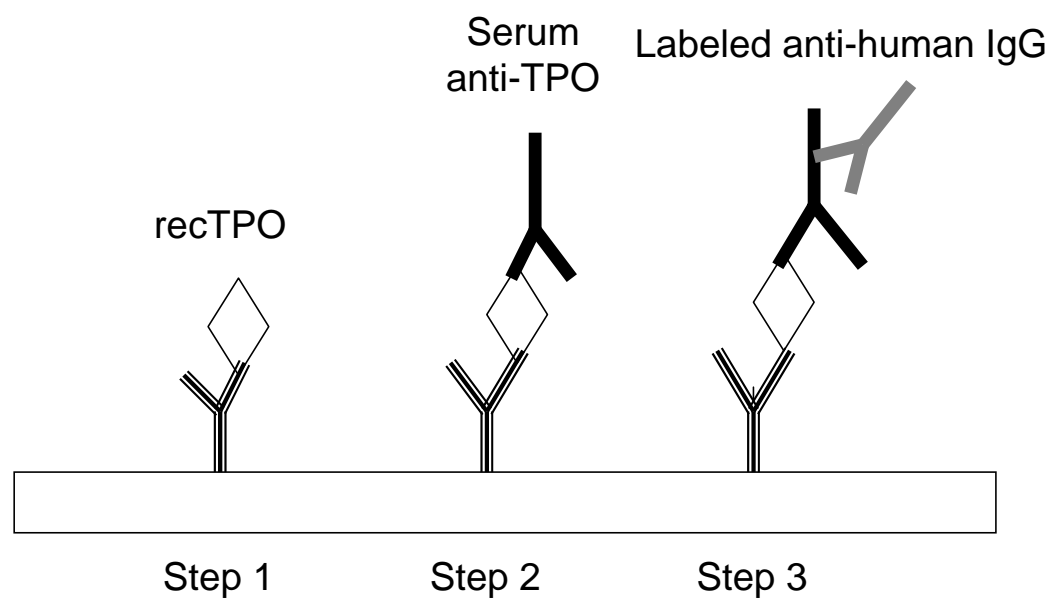

Fig. (1). Principles of sandwich ELISA for anti-TPO detection.

Anti-TPO precoated ELISA plates are saturated with recombinant human TPO (recTPO) (step 1). After washing, patient sera is added and anti-TPO (if present) binds to recTPO (step 2). Anti-human IgG conjugated with alkanine phosphatase is added (step 3) and color is measured at $405 \mathrm{~nm}$ after adding the substrate solution. Positive cut-off is set as the mean OD of 30 sera from healthy donors plus three standard deviations [53].

esis [84,85]. Single point c-mpl mutations characterize the rare congenital amegakaryocytic thrombocytopenia [86].

Experimental data have documented that TPO mRNA expression is stable in liver and kidneys and therefore serum levels are regulated by megakaryocyte mass [87,88]. Efforts to correlate peripheral platelet number with TPO levels in various disorders have initially faltered probably due to the wide range of values of both parameters. In the advent of newer quantitive ELISA, TPO levels were measured for both patients and healthy individuals, with levels for the latter varying usually below $200 \mathrm{pg} / \mathrm{ml}$. In contrast, TPO levels in thrombocytopenic patients are higher compared to normal sera. An impressive exception is AITP, with TPO levels being disproportionally lower than expected based on platelet count [89-93]. TPO levels are expected to be high in decreased platelet production (aplastic anemias, myelotoxic therapies) and inversely correlate with platelet count. On the contrary, in AITP where decreased platelet survival is expected but megakaryocyte mass is normal or increased, TPO levels are low [94-96]. In the only prospective study of TPO levels in AITP, its concentrations were comparable to normal volunteers and no negative correlation was documented with platelet numbers [97]. In chronic hepatic disease TPO levels are also low probably due to decreased hepatic synthesis [98,99].

Fureder [100] was the first to detect naturally occurring autoantibodies against thrombopoietin (anti-TPO) in 23\% of SLE patients and correlate their presence with lower platelet counts, but he failed to display a difference in TPO levels. TPO levels, though high compared to normal controls and consistent with disease activity and complement level, did not correlate with platelet count. In contrast, anti-TPO autoantibodies are not a characteristic of AITP patients [97]. In the only reference of amegakaryocytic thrombocytopenia related to anti-TPO autoantibodies, TPO levels and platelet count increased as antibody titer decreased during immunosuppressive treatment with cyclosporine [101]. A recent analysis confirmed the presence of anti-TPO antibodies in SLE sera (Fig. 1), and excluded their presence in rheumatoid arthritis and primary Sjogren patients who served as controls.
Although anti-TPO positive patients showed no statistically significant differences in platelet count at specimen collection, longitudinal analysis revealed sustained lower platelet levels and lower circulating levels of TPO [53]. High concentrations of antibodies may bind avidly with natural TPO enabling systemic TPO to be stripped and eliminated by capturing the protein in immune complexes. Hence, a number of SLE patients produce antibodies that are likely to directly neutralize their own TPO, indicating their bimodal nature: First, by engendering immune-complexes, a non-specific mechanism that enhances peripheral platelet consumption [52, 102-104]. Second, by decreasing the effective TPO concentrations for stimulating megakaryopoiesis [53].

To support this hypothesis, SLE sera were incubated in vitro to assess the effect on CFU-MK. Anti-TPO positive sera significantly inhibited mature CFU-MK compared to anti-TPO negative SLE sera and were associated with lower circulating TPO concentrations. TPO-induced CFU-MK are small and mature, with low proliferative capacity, suggesting that TPO works mostly late in megakaryocyte progenitor development $[71,105]$. These findings suggest an antibodyassociated restriction of the TPO-mediated effect on megakaryopoiesis. In conclusion, the capture and elimination/neutralization of circulating TPO by the antibodies may result in lower effective cytokine concentration to support megakaryopoiesis [106].

\section{BONE MARROW IN SLE THROMBOCYTOPENIA: A TARGET OR A CAUSE OF AUTOIMMUNITY?}

There are several indications for faulty hemopoiesis in SLE, most of which are attributed to the presence of autoreactive lymphocytes and the effect of proinflammatory cytokines [107,108]. The pathophysiologic disturbance includes the inhibition of colony formation and apoptosis through immunologic processes, as autoreactive lymphocytes are detected in bone marrow cultures [107,109] and their removal from bone marrow suspension increases the clonogenic potential of hemopoetic progenitor cells [110]. A recent study showed an increased expression of the FAS antigen in CD34+ cells of SLE patients [111] and a significant 


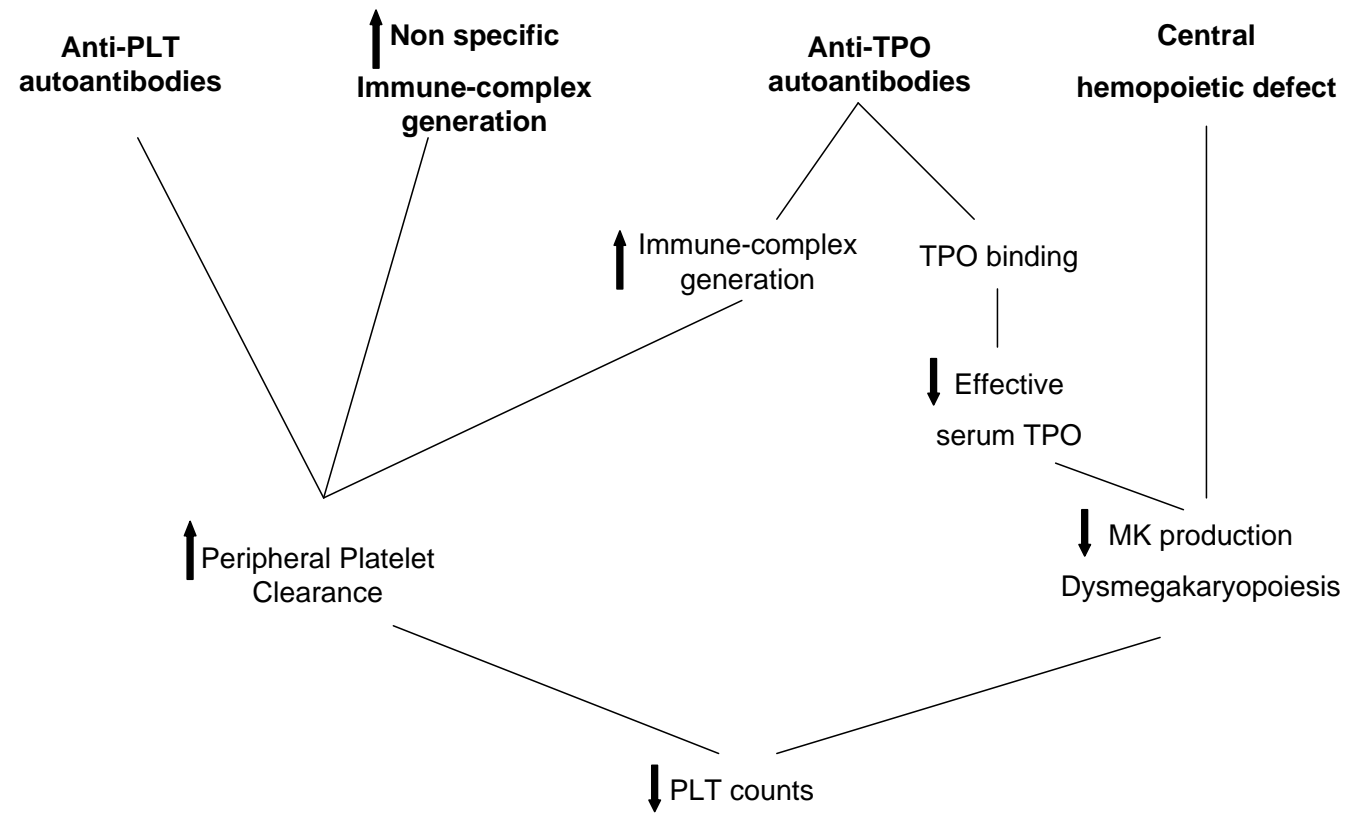

Fig. (2). Summary of mechanisms implicated in SLE thrombocytopenia.

correlation of apoptotic cells with FAS+ cells in the CD34+ compartment is observed, suggesting that the Fas signaling pathway is implicated in the induction of apoptosis of hemopoietic progenitor cells. Albeit increased expression of Fas does not invariably lead to apoptotic death [112], its implication in stem cell apoptosis is sufficiently documented in various diseases $[113,114]$. The same study documented a defect in the bone marrow microenvironment, leading to a decreased support of hemopoiesis in culture systems and a decrease in both primitive CD34+/CD38- and committed CD34+/CD38+ progenitor cells.

Current knowledge of Mesenchymal stem cells (MSCs) is primarily derived from studies performed on ex vivo expanded cells. There is a general consensus that MSCs are residents of the microenvironment and play a role in supporting hematopoiesis. An emerging body of data indicate that MSCs possess immunomodulatory properties and may play specific roles as immunomodulators in maintenance of peripheral tolerance, transplantation tolerance, tumor evasion, fetal-maternal tolerance, as well as autoimmunity $[115,116]$. In vitro studies suggest T-cell suppression and inhibition of differentiation of dendritic cells.

Recent observations suggested that MSCs from patients with autoimmune diseases are affected. MSCs derived from the BM of patients with severe aplastic anemia are deficient in their ability to suppress T-cell proliferation and cytokine release [117]. Whether these defects are relevant for the pathogenesis of aplastic anemia remains to be shown. Both stromal and endothelial progenitors in patients with systemic sclerosis also have been reported to be functionally impaired, showing a reduced proliferation and differentiation capacity. It has been suggested that the functional impairment of the BM microenvironment may be impicated in the impaired vasculogenesis in scleroderma [118]. It may therefore be hypothesized that the immunosuppressive capacities of MSCs might play a role in the BM microenvironment to create an immunoprivileged site that protects primitive stem cells from the bystander effects of local immune responses. Bone mar- row MSCs of SLE patients display functional abnormalities and decreased hemopoietic recovery after MSCs infusion is observed in experimental models exposed to chemotherapy [119]. Theoretically, the immunosuppressive properties of MSCs create an immunoprivileged bone marrow microenvironment that protects hemopoietic progenitor cell from immune-mediated destruction, and these cells might be implicated in the pathogenesis of cytopenias in SLE [120].

Morphologically, in SLE patients with cytopenias, bone marrow changes include decreased cellularity, polyclonal B and $\mathrm{T}$ cell aggregations, and stromal changes (including oedema, fibrosis and vascular changes) [121]. Dysplastic changes were a uniform finding in all hemopoietic lineages (dysmyelopoiesis with maturation arrest, dyserythropoiesis and dysmegakaryopoiesis) with disorganized microarchitecture. Megakaryocytic atypias included hypolobulated nucleus, pyknotic appearance with denuded cytoplasms (naked MKs) and other morphologic abnormalities of differentiation. Finally, abnormal localization of immature precursors without a typical paratrabecular location (ALIP clusters) have been observed and correlated with the degree of anemia $[53,121]$. This finding has so far been linked to myelodyplastic syndromes. Therefore, bone marrow is considered as a target organ of autoimmunity in SLE and associated cytopenias.

\section{Epilogue}

The extent of interactions, the sequence of events and the magnitude of effect for each mechanism remain partially inconclusive. Antiplatelet antibodies are neither specific nor sensitive in SLE, despite macrophage mediated clearance being the best documented mechanism of platelet destruction. Anti-TPO antibodies have a persistent but weak effect on platelet counts through a presumed thrombopoietindependent, antibody-mediated inhibition of megakaryopoiesis. Bone marrow damage may largely determine the extent and severity of thrombocytopenia as it is a uniform finding in SLE thrombocytopenia and other cytopenias (Fig. 2). 
Bone marrow damage itself may be a secondary event in the context of SLE immunologic disturbance or alternatively, a primary defect through MSCs abnormalities that generate and perpetuate a central hemopoietic defect and participate in autoantibody generation and immunologic phenomena in SLE. The latter effect may be mediated through a disruption of normal immunomodulatory mechanisms in the bone marrow.

Immunosuppressive therapy has been regarded as the mainstay of treatment for SLE-associated thrombocytopenia [5]. In a recent review series, B-cell depletion using antiCD20 (rituximab) has been regarded an effective alternative option in AITP [122] with an overall response rate of $62.5 \%$ in adults. An emerging body of data in SLE suggests that rituximab may also be highly effective in SLE cytopenias [123] through a mechanism that also involves the reduction of the pathogenic antibodies [123,124]. Second-generation thrombopoietic agents have been used in clinical trials to stimulate platelet production in AITP patients who are not responsive to standard treatments. These new molecules bear no structural resemblance to TPO but still bind and activate the TPO receptor. Romiplostin [125] and eltrombopag [126] have been successfully used in refractory AITP. Ongoing phase III clinical trials will reveal the potential of these agents in the management of AITP prior to splenectomy and for long-term maintenance therapy, as well as their relative benefit compared with standard care treatment [127]. These agents may also prove effective in SLE thrombocytopenia, where an impaired platelet production is one of the underlying mechanisms.

\section{ABBREVIATION LIST}

AITP $=$ Autoimmune Thrombocytopenic Purpura
CFU $=$ Colony Forming Unit
ELISA $=$ Enzyme Linked Immunosorbent Assay
MAIPA $=$ Antigens
MK $=$ Megakaryocyte
MSCs $=$ Mesenchymal Stem Cells
SLE $=$ Systemic Lupus Erythematosus
TPO $=$ Thrombopoietin
PLT $=$ Platelets

\section{REFERENCES}

[1] Ziakas PD, Giannouli S, Zintzaras E, Tzioufas AG, Voulgarelis M. Lupus thrombocytopenia: clinical implications and prognostic significance. Ann Rheum Dis 2005; 64: 1366-9.

[2] Ziakas PD, Dafni UG, Giannouli S, Tzioufas AG, Voulgarelis M. Thrombocytopaenia in lupus as a marker of adverse outcome-seeking Ariadne's thread. Rheumatology (Oxford) 2006; 45: 12615.

[3] Ziakas PD, Poulou LS, Giannouli S, Tzioufas AG, Voulgarelis M. Thrombocytopenia in lupus: baseline $\mathrm{C} 3$ as an independent risk factor for relapse. Ann Rheum Dis 2007; 66: 130-1.

[4] Fernández M, Alarcón GS, Apte M, Andrade RM, Vilá LM, Reveille JD: LUMINAStudy Group. Systemic lupus erythematosus in a multiethnic US cohort: XLIII. The significance of thrombocytopenia as a prognostic factor. Arthritis Rheum 2007; 56: 614-21.

[5] Voulgarelis M, Ziakas PD, Tzioufas AG. Current concepts in SLE thrombocytopenia: From pathophysiology to therapeutic interventions. Curr Rheumatol Rev 2006: 359-67.
[6] Harrington WJ, Minnich V, Hollingsworth JW, Moore CV. Demonstration of a thrombocytopenic factor in the blood of patients with thrombocytopenic purpura. 1951. J Lab Clin Med 1990; 115: 636-45.

[7] Kurata Y, Hayashi S, Kosugi S, et al. Elevated platelet-associated IgG in SLE patients due to anti-platelet autoantibody: differentiation between autoantibodies and immune complexes by ether elution. Br J Haematol 1993; 85: 723-8.

[8] Michel M, Khellaf M, Desforges L, et al. Autoimmune thrombocytopenic Purpura and Helicobacter pylori infection. Arch Intern Med 2002; 162: 1033-6.

[9] Ruggeri ZM, Zimmerman TS, Russell S, Bader R, De Marco L. von Willebrand factor binding to platelet glycoprotein $\mathrm{Ib}$ complex. Methods Enzymol 1992; 215: 263-75.

[10] Phillips DR, Charo IF, Parise LV, Fitzerald LA. The platelet membrane glycoprotein IIb/IIIa complex. Blood 1988; 71: 831-43.

[11] Kieffer N, Phillips DR. Platelet membrane glycoproteins: functions in cellular interactions. Annu Rev Cell Biol 1990; 6: 329-57.

[12] Tsuji T, Osawa T. Structures of the carbohydrate chains of membrane glycoproteins IIb and IIIa of human platelets. J Biochem 1986; 100: 1387-98.

[13] Steiner B, Parise LV, Leung B, Phillips DR. Ca2p dependent structural transitions of the platelet glycoprotein IIb-IIIa complex. Preparation of stable glycoprotein IIb and IIIa monomers. J Biol Chem 1991; 266: 14986-91.

[14] Nurden AT, Caen JP. An abnormal platelet glycoprotein pattern in three cases of Glanzmannı's thrombasthenia. Br J Haematol 1974; 28: 253-60.

[15] Phillips DR, Jenkins CS, Luscher EF, Larrieu M. Molecular differences of exposed surface proteins on thrombasthenic platelet plasma membranes. Nature 1975; 257: 599-600.

[16] Lopez JA. The platelet glycoprotein Ib-IX complex. Blood Coagul Fibrinolysis 1994; 5: 97-119.

[17] Clemetson KJ, McGregor JL, James E, Dechavanne M, Lüscher EF. Characterization of platelet membrane glycoprotein abnormalities in Bernard-Soulier syndrome and comparison with normal by surface-labelling techniques and high-resolution two-dimensional gel electrophoresis. J Clin Invest 1982; 70: 304-11.

[18] Santoro SA. Molecular basis of platelet adhesion to collagen. In: Jamieson GA, editor. Platelet membrane receptors: molecular biology, immunology, biochemistry and pathology. New York: Lass, 1988; 291-314

[19] Brooks DG, Qiu WQ, Luster AD, Ravetch JV. Structure and expression of human IgG FcRII(CD32). Functional heterogeneity is encoded by the alternatively spliced products of multiple genes. J Exp Med 1989; 170: 1369-85.

[20] Fossati G, Bucknall RC, Edwards SW. Fcgamma receptors in autoimmune diseases. Eur J Clin Invest 2001; 31: 821-31.

[21] Ericson SG, Coleman KD, Wardwell K, et al. Monoclonal antibody 197 (anti-Fc gamma RI) infusion in a patient with immune thrombocytopenia purpura (ITP) results in down-modulation of $\mathrm{Fc}$ gamma RI on circulating monocytes. Br J Haematol 1996; 92: 718 24.

[22] Flesch BK, Achtert G, Neppert J. Inhibition of monocyte and polymorphonuclear granulocyte immune phagocytosis by monoclonal antibodies specific for Fc gamma RI, II and III. Ann Hematol 1997; 74: $15-22$.

[23] Clarkson SB, Bussel JB, Kimberly RP, Valinsky JE, Nachman RL, Unkeless JC. Treatment of refractory immune thrombocytopenic purpura with an anti-Fc gamma-receptor antibody. N Engl J Med 1986; 314: 1236-9.

[24] Fehr J, Hofmann V, Kappeler U. Transient reversal of thrombocytopenia in idiopathic thrombocytopenic purpura by high-dose intravenous gamma globulin. N Engl J Med 1982; 306: 1254-8.

[25] Cooper N, Heddle NM, Haas M, et al. Intravenous (IV) anti-D and IV immunoglobulin achieve acute platelet increases by different mechanisms: modulation of cytokine and platelet responses to IV anti-D by FcgammaRIIa and FegammaRIIIa polymorphisms. Br J Haematol 2004; 124: 511-8.

[26] Samuelsson A, Towers TL, Ravetch JV. Anti-inflammatory activity of IVIG mediated through the inhibitory Fc receptor. Science 2001; 291: 484-6.

[27] Jin F, Balthasar JP. Mechanisms of intravenous immunoglobulin action in immune thrombocytopenic purpura. Hum Immunol 2005; 66: 403-10. 
[28] Jackson DP, Schmid HJ, Zieve PD. Nature of a platelet agglutinating factor in serum of patients with idiopathic thrombocytopenic purpura. J Clin Invest 1963; 42: 383-90.

[29] Aster RH, Enright SE. A platelet and granulocyte membrane defect in paroxysmal nocturnal hemoglobinuria: usefulness for the detection of platelet antibodies. J Clin Invest 1969; 48: 1199-210.

[30] Hirschman RJ, Shulman NR. The use of platelet serotonin release as a sensitive method for detecting antiplatelet antibodies and a plasma anti-platelet factor in patients with idiopathic thrombocytopenic purpura. Br J Haematol 1973; 24: 793-802.

[31] McMillan R, Smith RS, Longmire RL, Yelenosky R, Reid RT, Craddock CG. Immunoglobulins associated with human platelets. Blood 1971; 37: 316-22.

[32] Dixon R, Rosse W, Ebbert L. Quantitative determination of antibody in idiopathic thrombocytopenic purpura. N Engl J Med 1975; 292: 230-6.

[33] Luiken GA, McMillan R, Lightsey AL, et al. Platelet-associated IgG in immune thrombocytopenic purpura. Blood 1977; 50: 31725.

[34] George JN. The origin and significance of platelet IgG. In: Kunicki TJ, George JN, Eds. Platelet immunobiology, molecular and clinical aspects. Philadelphia, PA: JB Lippincott, 1989: 305-36.

[35] George JN. Platelet immunoglobulin G: its significance for the evaluation of thrombocytopenia and for understanding the origin of a-granule proteins. Blood 1990; 76: 859-70.

[36] Kelton JG, Neame PB, Bishop J, Ali M, Gauldie J, Hirsh J. The direct assay for platelet-associated $\operatorname{IgG}(\mathrm{PAIgG})$ : lack of association between antibody level and platelet size. Blood 1979; 53: 7380.

[37] Kelton JG, Giles AR, Neame PB, Powers P, Hageman N, Hirsch J. Comparison of two direct assays for platelet-associated $\mathrm{IgG}$ (PAIgG) in assessment of immune and nonimmune thrombocytopenia. Blood 1980; 55: 424-9.

[38] Tsubakio T, Kurata Y, Yonezawa T, Kitani T. Quantification of platelet-associated IgG with competitive solid-phase enzyme immunoassay. Acta Haematol 1981; 66: 251-6.

[39] LoBuglio AF, Court WS, Vinocur L, Maglott G, Shaw GM. Immune thrombocytopenic purpura. Use of a 125I-labeled antihuman $\mathrm{IgG}$ monoclonal antibody to quantify platelet-bound IgG. N Engl J Med 1983; 309: 459-63.

[40] Court WS, Bozeman JM, Soong S, Saleh MN, Shaw DR, LoBuglio AF. Platelet-surface bound IgG in patients with immune and nonimmune thrombocytopenia. Blood 1987; 69: 278-83.

[41] George JN. Platelet IgG: measurement, interpretation and clinical significance. Prog Hemost Thromb 1991; 10: 97.

[42] Chong BH, Keng TB. Advances in the diagnosis of idiopathic thrombocytopenic purpura. Semin Hematol 2000; 37: 249-60.

[43] Kiefel V, Santoso S, Weisheit M, Müeller-Eckhardt C. Monoclonal antibody-specific immobilization of platelet antigens (MAIPA): a new tool for the identification of platelet-reactive antibodies. Blood 1987; 70: 1722-6.

[44] Brighton TA, Evans S, Castaldi PA, Chesterman CN, Chong BH. Prospective evaluation of the clinical usefulness of an antigenspecific assay (MAIPA) in idiopathic thrombocytopenic purpura and other immune thrombocytopenias. Blood 1996; 88: 194-201.

[45] Warner MN, Moore JC, Warkentin TE, Santos AV, Kelton JG. A prospective study of protein-specific assays used to investigate idiopathic thrombocytopenic purpura. Br J Haematol 1999; 104: 442-7.

[46] Raife TJ, Olson JD, Lentz SR. Platelet antibody testing in idiopathic thrombocytopenic purpura. Blood 1996; 89: 1112-4.

[47] Berchtold P, Muller D, Beardsley D, et al. International study to compare antigen-specific methods used for the measurement of antiplatelet autoantibodies. Br J Haematol 1997; 96: 477-83.

[48] Pereira J, Accatino L, Alfaro J, Brahm J, Hidalgo P, Mezzano D. Platelet autoantibodies in patients with chronic liver disease. Am J Hematol 1995; 50: 173-8.

[49] Galli M, Daldossi M, Barbui T. Anti-glycoprotein Ib/IX and IIb/IIIa antibodies in patients with antiphospholipid antibodies. Thromb Haemost 1994; 71: 571-5.

[50] Taub JW, Warrier I, Holtkamp C, Beardsley DS, Lusher JM. Characterization of autoantibodies against the platelet glycoprotein antigens $\mathrm{IIb} / \mathrm{III}$ in childhood idiopathic thrombocytopenic purpura. Am J Hematol 1995; 48: 104-7.

[51] McMillan R. Immune thrombocytopenia. Clin Haematol 1983; 12: 69-88.
[52] McMillan R. Autoantibodies and autoantigens in chronic immune thrombocytopenic purpura. Semin Hematol 2000; 37: 239-248.

[53] Ziakas PD, Routsias JG, Giannouli S, Tasidou A, Tzioufas AG, Voulgarelis M. Suspects in the tale of lupus-associated thrombocytopenia. Clin Exp Immunol 2006; 145: 71-80.

[54] Cines DB, Blanchette VS. Immune thrombocytopenic purpura. N Engl J Med 2002; 346: 995-1008.

[55] Semple JW. Immune pathophysiology of autoimmune thrombocytopenic purpura. Blood Rev 2002; 16: 9-12.

[56] Ogawara $\mathrm{H}$, Handa $\mathrm{H}$, Morita $\mathrm{K}$, et al. High Th1/Th2 ratio in patients with chronic idiopathic thrombocytopenic purpura. Eur J Haematol 2003; 71: 283-8.

[57] Panitsas FP, Theodoropoulou M, Kouraklis A, et al. Adult chronic idiopathic thrombocytopenic purpura (ITP) is the manifestation of a type-1 polarized immune response. Blood 2004; 103: 2645-7.

[58] Agarwal SK, Marshall GD Jr. Dexamethasone promotes type 2 cytokine production primarily through inhibition of type 1 cytokines. J Interferon Cytokine Res 2001; 21: 147-55.

[59] Boshkov LK, Kelton JG, Halloran PF. HLA-DR expression by platelets in acute idiopathic thrombocytopenic purpura. $\mathrm{Br} \mathrm{J}$ Haematol 1992; 81: 552-7.

[60] Semple JW, Milev Y, Cosgrave D, et al. Differences in serum cytokine levels in acute and chronic autoimmune thrombocytopenic purpura: relationship to platelet phenotype and antiplatelet T-cell reactivity. Blood 1996; 87: 4245-54.

[61] Lazarus AH, Ellis J, Semple JW, Mody M, Crow AR, Freedman J. Comparison of platelet immunity in patients with SLE and with ITP. Transfus Sci 2000; 22: 19-27.

[62] Roark JH, Bussel JB, Cines DB, Siegel DL. Genetic analysis of autoantibodies in idiopathic thrombocytopenic purpura reveals evidence of clonal expansion and somatic mutation. Blood 2002; 100: 1388-98.

[63] Samuel H, Nardi M, Karpatkin M, Hart D, Belmont M, Karpatkin S. Differentiation of autoimmune thrombocytopenia from thrombocytopenia associated with immune complex disease: systemic lupus erythematosus, hepatitis-cirrhosis, and HIV-1 infection by platelet and serum immunological measurements. Br J Haematol 1999; 105: 1086-91.

[64] Pujol M, Ribera A, Vilardell M, Ordi J, Feliu E. High prevalence of platelet autoantibodies in patients with systemic lupus erythematosus. Br J Haematol 1995; 89: 137-41.

[65] deSauvage FJ, Carver-Moore K, Luoh SM, et al. Stimulation of megakaryocytopoiesis by the c-Mpl ligand. Nature 1994; 369: 5338.

[66] Lok S, Kaushansky K, Holly RD, et al. Cloning and expression of murine thrombopoietin cDNA and stimulation of platelet production in vivo. Nature 1994; 369: 565-8.

[67] Bartley TD, Bogenberger J, Hunt $\mathrm{P}$, et al. Identification and cloning of a megakaryocyte growth and development factor that is a ligand for the cytokine receptor Mpl. Cell 1994; 77: 1117-24.

[68] Kato T, Ogasmi K, Shimada Y, et al. Purification and characterization of thrombopoietin. J Biochem 1995; 118: 229-36.

[69] Kuter D, Beeler DL, Rosenberg RD. The purification of megapoietin: a physiological regulator of megakaryocyte growth and platelet production. Proc Natl Acad Sci USA 1994; 91: 11104-8.

[70] Banu N, Wang JF, Deng B, Groopman JE, Avraham H. Modulation of megakaryocytopoiesis by thrombopoietin: the c-Mpl ligand. Blood 1995; 86: 1331-8.

[71] Kaushansky K. Thrombopoietin: the primary regulator of platelet production. Blood 1995; 86: 419-31.

[72] Zucker-Franklin D, Kaushansky K. Effect of thrombopoietin on the development of megakaryocytes and platelets: an ultrastructural analysis. Blood 1996; 88: 1632-8.

[73] Choi ES, Hokom M, Bartley T, et al. Recombinant human megakaryocyte growth and development factor (rHuMGDF) a ligand for $\mathrm{c}-\mathrm{Mpl}$, produces functional human platelets in vitro. Stem Cells 1995; 13: 317-22.

[74] Debili N, Wendling F, Cosman D, et al. The Mpl receptor is expressed in the megakaryocytic lineage from late progenitors to platelets. Blood 1995; 85: 391-401.

[75] Rasko JEJ, O’Flaherty E, Begley CG. Mpl ligand (MGDF) alone and in combination with stem cell factor (SCF) promotes proliferation and survival of human megakaryocyte, erythroid and granulocyte/macrophage progenitors. Stem Cells 1997; 15: 33-42.

[76] Young JC, Bruno E, Luens KM, Wu S, Backer M, Murray LJ. Thrombopoietin stimulates megakaryocytopoiesis, myelopoiesis, 
and expansion of CD34p progenitor cells from single CD34p, Thy 1b, LIN- primitive progenitor cells. Blood 1996; 88: 1619-31.

[77] Kobayashi M, Laver JH, Kato T, Miyazaki H, Ogawa M. Thrombopoietin supports proliferation of human primitive hematopoietic cells in synergy with steel factor and/or interleukin-3. Blood 1996; 88: 429-36.

[78] Murray LJ, Mandich D, Bruno E, et al. Fetal bone marrow CD34pCD41p cells are enriched for multipotent hematopoietic progenitors, but not for pluripotent stem cells. Exp Hematol 1996; 24: 236-45.

[79] Nichol JL, Hokom MM, Hornkohl A, et al. Megakaryocyte growth and development factor: analyses of in vitro effects on human megakaryopoiesis and endogenous serum levels during chemotherapy-induced thrombocytopenia. J Clin Invest 1995; 95: 2973-8.

[80] Hunt P, Li YS, Nichol JL, et al. Purification and Biologic characterization of plasma-derived megakaryocyte growth and development factor. Blood 1995; 86: 540-7.

[81] Angchaisuksiri P, Carlson PL, Dessypris EN. Effects of recombinant human thrombopoietin on megakaryocyte colony formation and megakaryocyte ploidy by human CD34p cells in a serum-free system. Br J Haematol 1996; 93: 13-7.

[82] Nishihira H, Toyoda Y, Miyazaki H, Kigasawa H, Ohsaki E. Growth of macroscopic human megakaryocyte colonies from cord blood in culture with recombinant human thrombopoietin (c-mpl ligand) and the effects of gestational age on frequency of colonies. Br J Haematol 1996; 92: 23-8.

[83] Vigon I, Mornon JP, Cocault L, et al. Molecular cloning and characterization of MPL, the human homolog of the v-mpl oncogene: identification of a member of the hematopoietic growth factor receptor superfamily. Proc Natl Acad Sci USA 1992; 89: 5640-4.

[84] Solar GP, Kerr WG, Zeigler FC, et al. Role of c-mpl in early hematopoiesis. Blood 1998; 92: 4-10.

[85] Ballmaier M, Germeshausen M, Krukemeier S, Welte K. Thrombopoietin is essential for the maintenance of normal hematopoiesis in humans: development of aplastic anemia in patients with congenital amegakaryocytic thrombocytopenia. Ann NY Acad Sci 2003; 996: 17-25.

[86] Ballmaier M, Germeshausen M, Schulze H, et al. c-mpl mutations are the cause of congenital amegakaryocytic thrombocytopenia. Blood 2001; 97: 139-46.

[87] Fielder PJ, Gurney AL, Stefanich E, et al. Regulation of thrombopoietin levels by c-mpl mediated binding to platelets. Blood 1996; 87: 2154-61.

[88] Sungaran R, Markovic B, Chong BH. Localization and regulation of thrombopoietin mRNA expressionin human kidney, liver, bone marrow and spleen using in situ hybridization. Blood 1997; 89: 101-7.

[89] Chang M, Suen Y, Meng G, et al. Differential mechanisms in the regulation of endogenous levles of thrombopoietin and interleukin11 during thrombocytopenia: insight into the regulation of platelet production. Blood 1996; 88: 3354-62.

[90] Tahara T, Usuki K, Sato H, et al. A sensitive sandwich ELISA for measuring thrombopoietin in human serum: serum thrombopoietin levels in healthy volunteers and in patients with haemopoietic disorders. Br J Haematol 1996; 93: 783-8.

[91] Marsh JC, Gibson FM, Prue RL, et al. Serum thrombopoietin levels in patients with aplastic anaemia. Br J Haematol 1996; 95: 605-10.

[92] Usuki K, Tahara T, Iki S, et al. Serum thrombopoietin level in various hematological diseases. Stem Cells (Basel) 1996; 14: 55865

[93] Ichikawa N, Ishida F, Shimodaira S, Tahara T, Kato T, Kitano K. Regulation of serum thrombopoietin levels by platelets and megakaryocytes in patients with aplastic anaemia and idiopathic thrombocytopenic purpura. Thromb Haemost 1996; 76: 156-60.

[94] Hirayama Y, Sakamaki S, Matsunaga T, et al. Concentrations of thrombopoietin in bone marrow in normal subjects and in patients with idiopathic thrombocytopenic purpura, aplastic anemia, and essential thrombocythemia correlate with its mRNA expression of bone marrow stromal cells. Blood 1998; 92: 46-52.

[95] Emmons RV, Reid DM, Cohen RL, et al. Human thrombopoietin levels are high when thrombocytopenia is due to megakaryocyte deficiency and low when due to increased platelet destruction. Blood 1996; 87: 4068-71.

[96] Chang M, Suen Y, Meng G, et al. Regulation of TPO mRNA expression and protein production: TPO gene regulation appears post transcriptional, and endogenous levels are inverseley correlated to megakaryocyte mass and circulating platelet count. Blood 86: 368a, 1995 [abstr, suppl 1].

[97] Aledort LM, Hayward CP, Chen MG, Nichol JL, Bussel J. ITP Study Group. Prospective screening of 205 patients with ITP, including diagnosis, serological markers, and the relationship between platelet counts, endogenous thrombopoietin, and circulating antithrombopoietin antibodies. Am J Hematol 2004; 76: 205-13.

[98] Hamaguchi M, Yamada H, Morishima Y, et al. Serum thrombopoietin level after allogeneic bone marrow transplantation: Possible correlations with platelet recovery, acute graft-versus-host disease and hepatic veno-occlusive disease. Jpn Int J Hematol 1996; 64: 241-8.

[99] Martin TG 3rd, Somberg KA, Meng YG. Thrombopoietin levels in patients with cirrhosis before and after orthotopic liver transplantation. Ann Intern Med 1997; 127: 285-8.

[100] Fureder W, Firbas U, Nichol JL, et al. Serum thrombopoietin levels and anti-thrombopoietin antibodies in systemic lupus erythematosus. Lupus 2002; 11: 221-6.

[101] Shiozaki H, Miyawaki S, Kuwaki T, Hagiwara T, Kato T, Miyazaki H. Autoantibodies neutralizing thrombopoietin in a patient with amegakaryocytic thrombocytopenic purpura. Blood 2000; 95: 2187-8.

[102] King M, McDermott P, Schreiber AD. Characterization of the Fc gamma receptor on human platelets. Cell Immunol 1990; 128: 46279.

[103] Hed J. Role of complement in immune or idiopathic thrombocytopenic purpura. Acta Paediatr Suppl 1998; 424: 37-40.

[104] Spycher MO, Nydegger UE. Participation of the blood platelet in immune reactions due to platelet-complement interaction. Infusionsther Transfusionsmed 1995; 22: 36-43.

[105] Ryu KH, Chun S, Carbonierre S, Im SA, Kim HL, Shin MH. Apoptosis and megakaryocytic differentiation during ex vivo expansion of human cord blood CD34+ cells using thrombopoietin. $\mathrm{Br} \mathrm{J}$ Haematol 2001; 113: 470-8.

[106] Ziakas PD, Papadaki H, Psyllaki M, Voulgarelis M. AntiThrombopoietin antibodies suppress megakaryocytic colony formation in vitro in patients with systemic lupus erythematosus. Ann Rheum Dis 2008; 67: 1643-4.

[107] Otsuka T, Nagasawa K, Harada M, Niho Y. Bone marrow microenvironment of patients with systemic lupus erythematosus. J Rheumatol 1993; 20: 967-71.

[108] Tsokos GC. Lymphocytes, cytokines, inflammation, and immune trafficking. Curr Opin Rheumatol 1994; 6: 461-7.

[109] Berneman ZN, Chen ZZ, van Bockstaele D, Ramael M, Korthout $\mathrm{M}$, Peetermans ME. The nature of the adherent hemopoietic cells in human long-term bone marrow cultures (HLTBMCs): presence of lymphocytes and plasma cells next to the myelomonocytic population. Leukemia 1989; 3: 648-61.

[110] Nagafuji K, Shibuya T, Harada M, et al. Functional expression of Fas antigen (CD95) on hematopoietic progenitor cells. Blood 1995; 86: 883-9

[111] Papadaki HA, Boumpas DT, Gibson FM, et al. Increased apoptosis of bone marrow CD34+ cells and impaired function of bone marrow stromal cells in patients with systemic lupus eruthematosus. $\mathrm{Br}$ J Haematol 2001; 115: 167-74.

[112] Miyawaki T, Uehara T, Nibu R, et al. Differential expression of apoptosis-related Fas antigen on lymphocyte subpopulations in human peripheral blood. J Immunol 1992; 149: 3753-8.

[113] Maciejewski JP, Selleri C, Sato T, Anderson S, Young NS. Increased expression of Fas antigen on bone marrow CD34+ cells of patients with aplastic anaemia. Br J Haematol 1995; 91: 245-52.

[114] Saheki K, Fujimori Y, Takemoto Y, Kakishita E. Increased expression of Fas (APO-1, CD95) on CD34+ haematopoietic progenitor cells after allogeneic bone marrow transplantation. Br J Haematol 2000; 109: 447-52.

[115] Rasmusson I. Immune modulation by mesenchymal stem cells. Exp Cell Res 2006; 312: 2169-2179.

[116] Uccelli A, Moretta L, Pistoia V. Immunoregulatory function of mesenchymal stem cells. Eur J Immunol 2006; 36: 2566-2573.

[117] Bacigalupo A, Valle M, Podesta M, et al. T-cell suppression mediated by mesenchymal stem cells is deficient in patients with severe aplastic anemia. Exp Hematol 2005; 33: 819-827.

[118] Del Papa N, Quirici N, Soligo D, et al. Bone marrow endothelial progenitors are defective in systemic sclerosis. Arthritis Rheum 2006; 54: 2605-2615. 
[119] Sun LY, Zhang HY, Feng XB, Hou YY, Lu LW, Fan LM. Abnormality of bone marrow-derived mesenchymal stem cells in patients with systemic lupus erythematosus. Lupus 2007; 16: 121-8.

[120] Nauta AJ, Fibbe WE. Immunomodulatory properties of mesenchymal stromal cells. Blood 2007; 110: 3499-506.

[121] Voulgarelis M, Giannouli S, Tasidou A, Anagnostou D, Ziakas PD, Tzioufas AG. Bone marrow histological findings in systemic lupus erythematosus with hematologic abnormalities: a clinicopathological study. Am J Hematol 2006; 81: 590-7.

[122] Arnold DM, Dentali F, Crowther MA, et al. Systematic review: efficacy and safety of rituximab for adults with idiopathic thrombocytopenic purpura. Ann Intern Med 2007; 146: 25-33.

[123] Lindholm C, Börjesson-Asp K, Zendjanchi K, Sundqvist AC, Tarkowski A, Bokarewa M. Longterm clinical and immunological effects of anti-CD20 treatment in patients with refractory systemic lupus erythematosus. J Rheumatol 2008; 35: 826-33.
[124] Tomietto P, Gremese E, Tolusso B, Venturini P, De Vita S, Ferraccioli G. B cell depletion may lead to normalization of anti-platelet, anti-erythrocyte and antiphospholipid antibodies in systemic lupus erythematosus. Thromb Haemost 2004; 92: 1150-3.

[125] Kuter DJ, Bussel JB, Lyons RM, et al. Efficacy of romiplostim in patients with chronic immune thrombocytopenic purpura: a doubleblind randomised controlled trial. Lancet 2008; 371(9610): 395403.

[126] Bussel JB, Cheng G, Saleh MN, et al. Eltrombopag for the treatment of chronic idiopathic thrombocytopenic purpura. N Engl J Med 2007; 357: 2237-47.

[127] Stasi R, Evangelista ML, Amadori S. Novel thrombopoietic agents: a review of their use in idiopathic thrombocytopenic purpura Drugs 2008; 68: 901-12

(C) Panayiotis D. Ziakas; Licensee Bentham Open.

This is an open access article distributed under the terms of the Creative Commons Attribution License (http://creativecommons.org/licenses/by/2.5/), which permits unrestrictive use, distribution, and reproduction in any medium, provided the original work is properly cited. 